\title{
The Seismicity of Central America
}


This page is intentionally left blank 


\title{
The Seismicity \\ of Central America
}

A Descriptive Catalogue 1898-1995

\author{
N. N. Ambraseys \\ Imperial College, UK \\ R. D. Adams \\ International Seismological Centre, UK
}


Published by

Imperial College Press

57 Shelton Street

Covent Garden

London WC2H 9HE

\section{Distributed by}

World Scientific Publishing Co. Pte. Ltd.

P O Box 128, Farrer Road. Singapore 912805

USA office: Suite 1B, 1060 Main Street, River Edge, NJ 07661

UK office: 57 Shelton Street, Covent Garden, London WC2H 9HE

\section{British Library Cataloguing-in-Publication Data}

A catalogue record for this book is available from the British Library.

\section{THE SEISMICITY OF CENTRAL AMERICA}

\section{Copyright $\odot 2001$ by Imperial College Press}

All rights reserved. This book, or parts thereof, may not be reproduced in any form or by any means, electronic or mechanical, including photocopying, recording or any information storage and retrieval system now known or to be invented, without written permission from the Publisher.

For photocopying of material in this volume, please pay a copying fee through the Copyright Clearance Center, Inc., 222 Rosewood Drive, Danvers, MA 01923, USA. In this case permission to photocopy is not required from the publisher.

ISBN $\quad 1-86094-244-X$ 


\section{Preface}

This study is the culmination of several decades of work. Our involvement in the region has grown over the years as more information and different types of analysis have become available.

We have developed and improved our own techniques in earthquake location, determination of size and the analysis of felt effects throughout this period, and because of this sometimes take the opportunity in the text of reviewing techniques previously used by others, and of tracing the development of these analyses. Modern workers do not always realise the limitations imposed on their early colleagues by inadequate instrumentation, the paucity of knowledge of basic earth structure and sometimes lack of appreciation of the physical bases of the parameters they were seeking. An example is our full discussion of the development of the magnitude scales, and of our own use of $M_{S}$. Similarly, our location of early events by using the travel time of the maximum of the surface wave train has proved most useful.

Better information is continually becoming available, enabling earlier work to be reassessed. We were helped in our final analysis by the late availability of the catalogue of Engdahl et al. (1998), which applies improved location techniques to the larger events in the ISC catalogues since 1964, producing much more reliable estimates of focal depth.

The most substantial parts of this work are the appendices containing the catalogue of earthquake parameters, including about 1,800 events, and the detailed description of macroseismic effects of major earthquakes and those of special interest. The earlier part of the text is intended to help in the understanding of these sections and to explain the methods used in their compilation.

We have made use of work of many previous workers, some of which we criticise and in which we find errors. Naturally we hope that our work is an improvement, but it would be presumptuous to assume that it is error free. For these errors we offer apologies, and hope that others will be able to carry out further improvements. We believe, however, that this work is the most reliable and complete compilation of earthquake activity in Central America that is currently available, and hope that it will serve as a basis for fuller investigations of seismicity. 
This page is intentionally left blank 


\section{Acknowledgements}

We thank the following for help in collecting and assessing information:

Mrs M Laporte for field data from Costa Rica,

Dr L Feldman for retrieving unpublished information from repositories in Central America and USA,

Dr A Bodare for supplying reports of field work carried out in Central America by research students of the Royal Technical University of Stockholm,

Mr D White for assistance in the retrieval of data from the Public Records Office at Kew,

Mr J Vogt for newspaper data and unpublished reports kept in French and German repositories,

The Budesarchiv Abteilung, Potsdam, for copies of consular correspondence 1901-1910,

Libraries of the Royal Geographical Society, London, and the French Geographical Society, Paris,

Dr R White for providing us with copies of some early Wiechert seismograms from the Guatemala station,

Dr J J Bommer for information on earthquakes in El Salvador,

Dr $\mathrm{H}$ Bungum for advice on recent seismicity,

CEC National Scientific Cooperation Programme, Brussels, for support under contract CI1/CT94/1014, "Assessment of Seismic Hazard in El Salvador".

The computer re-location, and much of the text preparation has been carried out at the International Seismological Centre, in Berkshire, England over the last decade or so. We are grateful for the use of the Centre's facilities, which are funded by the Member organisations, including support from the U S National Science Foundation through grant EAR-9725096. Our sincere thanks are due the many staff members who helped with advice and practical assistance with computing and production of figures. Among those who made special contributions were Mr D M McGregor, 
Mrs A-R Surguy, Mr J C Harris and Ms A L Bird. Ms Bird made a particular contribution in producing the final text for printing. 


\section{Contents}

Preface $\quad$ v

Acknowledgements vii

Chapter 1 Introduction 1

1.1 Note on Transliteration . . . . . . . . . . . . . . . 2

Chapter 2 Instrumental Earthquake Location 3

2.1 General Principles ....................... 3

2.2 Agencies and Methods ................... 4

2.2.1 International Recording and Analysis ............ 4

2.2.2 Local and Regional Agencies . . . . . . . . . . . . . . . 6

2.2 .3 Special Studies and Relocations . . . . . . . . . . . . 6

2.2 .4 Our Relocations .................. 7

2.3 Location in Different Time Periods . . . . . . . . . . . . . 8

$2.3 .1 \quad \mathrm{Up}_{\mathrm{p}}$ to $1920 \ldots \ldots \ldots \ldots$

2.3 .2 From 1920 to $1950 \ldots \ldots \ldots \ldots$

2.3.3 From 1950 to $1963 \ldots \ldots \ldots \ldots$

2.3 .4 From 1964 to $1995 \ldots \ldots \ldots \ldots 11$

Chapter 3 Determination of Earthquake Size 13

3.1 General Principles . . . . . . . . . . . . . . . . . . . 13

3.2 Surface-Wave Magnitude $\left(M_{S}\right) \ldots \ldots \ldots \ldots$

3.2.1 Prague Formula for Surface-Wave Magnitude . . . . . . . . . . 14

3.2.2 Station Corrections for Magnitude . . . . . . . . . . . . . 16

3.2.3 Distance Correction for the Original Prague Formula . . . . . . . 17

3.2.4 Averaging Station Magnitudes to Give Event Magnitude $M_{S}$. . 18

3.2 .5 Errors in $M_{S}$ Determinations . . . . . . . . . . . . . . 20

3.3 Body-Wave Magnitude $\left(m_{b}\right) \ldots \ldots \ldots . \ldots \ldots$

3.4 Seismic Moment $\left(M_{O}\right) \ldots \ldots \ldots \ldots . \ldots \ldots$ 
3.5 Other Measures of Earthquake Size . . . . . . . . . . . . . . . . 21

3.6 Existing Magnitude Estimates for Our Study Area . . . . . . . . . . . 21

3.7 Our Redeterminations . . . . . . . . . . . . . . . 23

3.7.1 Choice of Magnitude Scale . . . . . . . . . . . . . . 23

3.7.2 Basic Amplitude and Period Data . . . . . . . . . . . . 24

3.7.3 Focal Depth. . . . . . . . . . . . . . . . . . . 24

3.7 .4 Variation with Time . . . . . . . . . . . . 24

3.7 .5 Practical Difficulties . . . . . . . . . . . . . . . . 26

3.7 .6 Summary ...................... 27

Chapter 4 Macroseismic Information and Location 29

$\begin{array}{lll}\text { Chapter 5 Description of Seismicity } & 31\end{array}$

$\begin{array}{lll}\text { Chapter } 6 & \text { Conclusions } & \mathbf{4 3}\end{array}$

Appendix A Case Histories of Earthquakes $\mathbf{4 5}$

A.1 Explanation . . . . . . . . . . . . . . . . . 45

A.2 Individual Case Histories . . . . . . . . . . . 46

Appendix B Parametric Catalogue of Earthquakes 223

B.1 Notes on Parametric Table . . . . . . . . . . . . . . . . 223

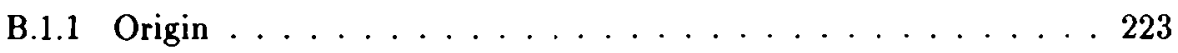

B.1.2 Agency ........................ . . 224

B.1.3 Size . . . . . . . . . . . . . . . . . . 224

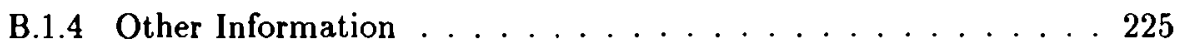

B.2 Parametric Table . . . . . . . . . . . . . . . . 225

$\begin{array}{ll}\text { References } & 287\end{array}$

$\begin{array}{ll}\text { Index } & 303\end{array}$ 